\title{
Cellulolytic Fungi Isolated by the Screened Substrate Method
}

The isolation of fungi from particles of soil placed on, or incorporated into nutrient agar media (e.g. WAKSMAN ${ }^{1}$, WARcu ${ }^{2}$ ) is an important method in helping to assess the activity and growth of such organisms in soils, whilst the utilization of individual substrates in soils has been elucidated by the use of agar media selective for particular nutritional groups of fungi (e.g. EGGins and PUGH ${ }^{3}$ ).

Such techniques, though, do not easily distinguish between active and dormant fungi, but Chesters using agar media contained within a glass tube pierced with open-ended invaginated capillaries, retrieved actively growing fungi from the soil. Modifications of this technique e.g. ThonnTon's ${ }^{5}$ screened immersion plates, have expanded our knowledge of fungi actively growing in soil, but as Chesters and Thornton ${ }^{3}$ pointed out, this method is selective for fungi able to grow rapidly under conditions of low oxygen tension.

Methods employing specific substrates (principally cellulosic) have been reviewed by HAzEU and EgGINs? but often these substrates have been specified degraded derivatives rather than intact cellulose; also, due to the difficulty of separating the deteriogen from adhering soil, there is often a danger during subsequent isolation of cultivating contaminants instead of the actual colonizers.

To obviate some of these difficulties, a technique has been evolved using a buried fibrous cotton cellulosic material which is screened from direct contamination by soil particles; in this way only actively growing hyphae are able to colonize the cellulosic substrate and the fungi responsible can be subsequently identified by subculturing.

The technique to be described utilizes Whatman chromatography paper obtainable with heat-rolled polythene backing (polythene coated 3MM Whatman chromatography paper). The main advantages of this as a model cellulosic substrate are the rigid exclusion of extraneous soluble substances during manufacture and also the ease of handling of such a substrate after the cellulose has been extensively broken down, due to the support provided by the relatively biologically inert polythene backing. It is thus possible to examine macroscopically and microscopically points of colonization by the obvious break-

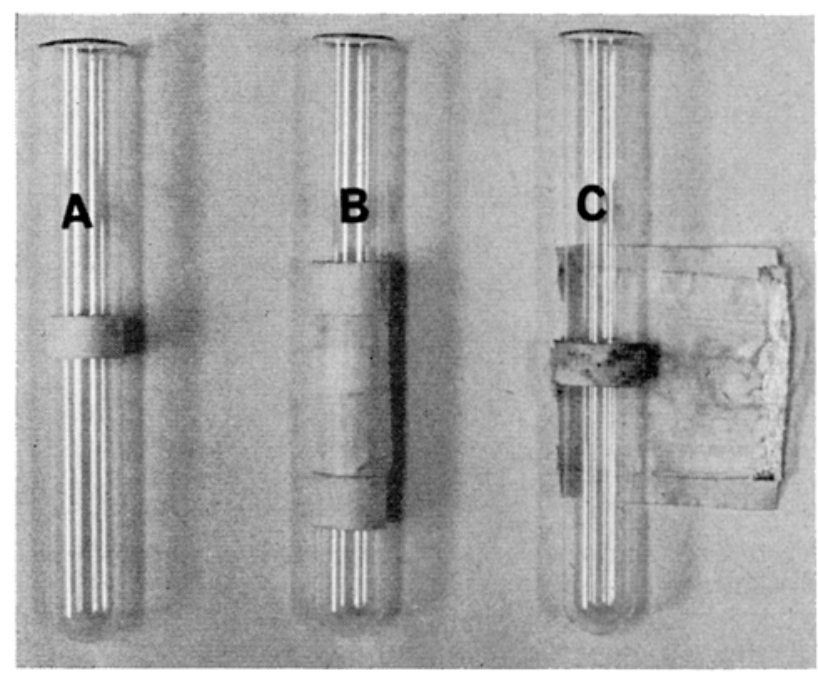

Screened substrate tubes. (A) The cellulose substrate strip in position. (B) The completed screened substrate tube before burial (C) The cellulose substrate strip showing colonization after 1 week at $45^{\circ} \mathrm{C}$ (fibre glass fabric tape partially removed). down of relatively natural fibrous cotton cellulose and also to isolate subsequently the individual deteriogens responsible. Furthermore the effects of various protective biocides can conveniently be studied. The polythenebacked chromatography paper is used in strips $0.5-1.0 \mathrm{~cm}$ wide on which may be absorbed additional nutrients (e.g. nutrient salts such as those used by EGGINS and PuGH ${ }^{3}$ ). These strips are installed in the soil wound round testtubes (polythene side innermost), (see Figure, A). Each strip is then covered with glass fibre fabric tape (e.g. 'E.C.T. 101' glass cloth tape, 2 inches wide by 0.003 inches thick; Turner Brothers Asbestos Co. Limited, Rochdale, England) which is then fastened by an adhesive tape of resin-backed glass fibre which is heat and water resistant. This covering of glass fibre fabric tape avoids contamination of the cellulosic substrate by soil particles, yet easily allows colonizing, growing hyphae to penetrate to the cellulosic substrate.

Such screened substrate tubes (see Figure, B) are then autoclaved together in covered beakers containing a few $\mathrm{ml}$ of water and stored for use.

The tubes may be buried in soil in situ or incubated in the laboratory in soil beakers. Tubes can be sacrificed at regular intervals, the glass fibre fabric tape removed, and the under-lying cellulose strip examined for colonization macroscopically and microscopically (see Figure, C). The polythene backing ensures easy handling. The strip may then be cut sterilely into small pieces (e.g. $0.5 \times 0.5 \mathrm{~cm}$ ) and plated out onto cellulose agar (EGGINS and PUGH ${ }^{\text {a }}$ ) where the Whatman chromatography cellulose powder as sole carbon source is similar to the cellulose of the strips. Cellulolytic fungi growing from the pieces of cellulose strip can then be identified and their cellulolytic activity determined by the clearing of the cellulose agar.

Experiments using this technique have emphasized the importance of screening the substrate from direct contact with the soil, whilst the use of the polythene backed cellulose has facilitated the closer study of the patterns of colonization of mesophilic and thermophilic fungi in situ. Detailed results will be published elsewhere.

Zusammenfassung. Eine neue Methode zur spezifischen Isolierung von zellulolytischen Bodenpilzen wird beschrieben: Als Substrat dient Whatman-Chromatographiepapier $3 \mathrm{~mm}$, rückseitig überschichtet mit Polythene. Ein Glasfasergewebe über dem Papierstreifen schützt vor dem direkten Kontakt des Substrats mit der Erde. Zellulolytische Pilze durchwachsen das Glasfasergewebe, bauen die Zellulose ab, wodurch eine direkte Mikroskopie der freigelegten Polytheneschicht ermöglicht wird.

\section{H. O. W. Eggins and A. O. Lloyd}

Biodeterioration Information Centre, Department of Biological Sciences, University of A ston in Birmingham, Birmingham, 4, and Catomance Limited, Welwyn Garden City (Herts., England), 27 December 1967.

1 S. A. Waksman, Science 44, 320 (1916).

2 J. H. WARCUP, Nature $166(1950)$.

3 H. O. W. EgGins and G. J. F. Pugm, Nature 193, 94 (1962).

4 C. G. C. Chesters, Trans Br. mycol. Soc. 24, 352 (1940).

b R. H. Thornton, Research, Lond. 5, 190 (1952).

- C. G. C. Chesters and R. H. Thornton, Trans. Br. mycol. Soc. 39, 301 (1956).

7 W. HAzEU and H. O. W. EgGins, Int. I3iodetn Bull. 2, 135 (1966). 